\title{
MICROSURGICAL RECONSTRUCTION DURING COVID-19 PANDEMIC SETTING: A SYSTEMATIC REVIEW AND CLINICAL APPLICATIONS
}

\author{
Parintosa Atmodiwirjo*), Mohamad Rachadian Ramadan, Nadhira Anindita Ralena, \& \\ Sara Ester Triatmoko \\ Reconstructive Microsurgery Section, Division of Plastic Surgery, Faculty of Medicine Universitas Indonesia, \\ dr. Cipto Mangunkusumo National Hospital. Jakarta, Indonesia
}

\begin{abstract}
Introduction: The outbreak of the novel coronavirus disease 2019 (COVID-19) has taken almost all countries worldwide. This situation has compromised the safety and health of all medical workers, including microsurgeons. Given that there have been various articles published about the recommendations in microsurgical reconstruction during the COVID-19 pandemic, We felt compelled to compile all relevant studies about the microsurgical reconstruction in the COVID-19 pandemic setting, describe the various actions from different perspectives, as well as providing suggestions based on evidence-based medicine.

Method: We did a systematic literature search using electronic databases such as PubMed, Embase, Medline, Wiley, and Cochrane using keywords reconstruction, Microsurgery, coronavirus, and COVID-19. All included studies were critically appraised and reviewed.

Results: Nine relevant articles were included for the final review, four of them were qualitative studies, and 5 were guidelines. Studies look at various surgeon's experiences from different healthcare systems during the COVID-19 pandemic. The focuses of the included studies are also diverse from head and neck surgery, breast surgery, limb surgery, and general Reconstructive Microsurgery.

Conclusion: Microsurgical reconstruction is not suggested to perform during the peak of the COVID-19 pandemic. It is indicated only if necessary after a rigorous review by the multi-disciplinary team. A full PPE, including a Powered Air Purifying Respirators (PAPR) system, fit-tested N95 respirator masks, face shield, and tight-fitting eye protection goggles, are recommended in performing the surgeries.

Keywords: Reconstructive Surgical Procedures, Microsurgery, COVID-19
\end{abstract}

\section{ABSTRAK}

Introduksi: Wabah penyakit novel coronavirus 2019 (COVID-19) telah merebak hampir di seluruh negara di dunia. Situasi ini telah membahayakan keselamatan dan kesehatan semua pekerja medis, termasuk ahli bedah mikro. Mengingat telah ada berbagai artikel yang dipublikasikankan tentang rekomendasi dalam rekonstruksi bedah mikro selama pandemi COVID-19, Kami terdorong untuk mengumpulkan semua studi yang relevan tentang rekonstruksi bedah mikro dalam situasi pandemi COVID-19, mendeskripsikan berbagai tindakan dari perspektif yang berbeda, juga memberikan saran berdasarkan evidence-based medicine.

Metode: Kami melakukan pencarian literatur sistematis menggunakan database elektronik seperti PubMed, Embase, Medline, Wiley, dan Cochrane menggunakan kata kunci rekonstruksi, bedah mikro, virus corona, dan COVID-19. Semua studi yang disertakan dinilai dan ditinjau secara kritis.

Hasil: Sembilan artikel yang relevan dimasukkan untuk tinjauan akhir, empat diantaranya adalah studi kualitatif dan 5 di antaranya adalah pedoman. Secara umum, penelitian melihat berbagai pengalaman ahli bedah, dari sistem perawatan kesehatan yang berbeda selama pandemi COVID-19. Fokus studi yang disertakan juga beragam mulai dari bedah kepala dan leher, bedah payudara, bedah tungkai, dan bedah mikro rekonstruktif umum.

Kesimpulan: Rekonstruksi bedah mikro tidak disarankan untuk dilakukan selama puncak pandemi COVID-19. Ini diindikasikan, hanya jika benar-benar diperlukan setelah tinjauan ketat oleh tim multidisiplin. APD lengkap termasuk sistem Powered Air Purifying Respirators (PAPR), masker respirator N95 yang telah teruji, pelindung wajah, dan kacamata pelindung yang ketat direkomendasikan dalam melakukan operasi.

Kata kunci: Prosedur Bedah Rekonstruksi, Bedah Mikro, COVID-19

Conflicts of Interest Statement:

The Author (s) listed in this manuscript declare the absence of any conflict of interest on the subject matter or materials discussed. 


\section{INTRODUCTION}

The outbreak of the novel coronavirus disease 2019 (COVID-19) has taken almost all countries worldwide. The number of infected people has increased at an unprecedented magnitude. Per June 27rd, 2020, there were 9.7 million total confirmed cases from all over the world. This condition has led to almost 500,000 deaths. Additional new cases are on the rise every day, and in most regions, the curve has not shown declining. This situation has compromised the safety and health of all medical workers, including reconstructive microsurgeons. ${ }^{1}$

This pandemic has led to overloading in hospital systems in most affected areas. The impact of this situation has led to sudden disruption in routine medical care, including for patients who required microsurgical reconstruction. Consequently, many routine visits of patients to outpatient clinics have been deferred too. ${ }^{2}$

Head and neck microsurgical reconstruction have been considered as the highrisk procedures for COVID-19 transmission due to high viral titers in the aerodigestive mucosal tract. Any head and neck procedure may easily aerosolize viral particles and created airborne transmission. ${ }^{2}$

There have been various articles published about the recommendations in microsurgical reconstruction during the COVID19 pandemic. Guidelines by Curigliano et al. and Hsieh et al. suggested that microsurgical procedures should not be undertaken during the peak of the COVID-19 pandemic. Nevertheless, delay in surgical procedures could increase the risk of disease progression, for example, in cancer patients, which contributes to the increasing number of mortality and morbidity. As published studies and guidelines only represent a local scope, it might not reflect the highly variably COVID-19 pandemic situations worldwide. Some of the published guidelines also focused only on one aspect in reconstructive microsurgical management, for example, head and neck, while reconstructive Microsurgery is a broad specialty that encompasses from head to toe. $3,4,5$
Therefore in this systematic review, we reviewed whether the COVID-19 pandemic leads to changes in reconstructive microsurgical practice. Furthermore, this review aimed to compile all relevant studies, guidelines, and recommendations for reconstructive microsurgery practice during the COVID-19 pandemic, describe various policies from the different health care systems and provide general suggestions based on evidence-based medicine.

\section{METHOD}

We conducted systematic and comprehensive literature searching on June 27th, 2020, using electronic databases PubMed, Embase, Medline, Wiley, and Cochrane with keywords including reconstruction, Microsurgery, coronavirus, and COVID-19.

Based on the search terms, we obtain 64 articles from 5 databases and other sources. Studies were filtered to avoid duplicates. Searching was proceeded using several inclusion criteria, such as; (1) Randomized controlled trials, cohort studies, observational studies, guidelines, consensus, and review; (2) Involving patients who underwent microsurgical reconstruction; (3) procedures performed during the COVID-19 pandemic. Meanwhile, studies were excluded in this review when they met the following criteria: (1) Expert experiences, short papers, letters; (2) Articles in languages other than English. We individually screened all articles for relevance and the availability of the full texts (Figures 1).

\section{RESULT}

Sixty articles were selected based on the title and abstract reading. Five articles were obtained from reference screening and included. After duplicates from different databases were removed, 53 papers remained. Forty-four articles were excluded from the review. The exclusion criteria were articles of expert opinions involving patients who underwent surgery other than reconstructive microsurgeries. We included nine articles for the final full-text review and quality assessment; four were qualitative studies, and 5 were guidelines (Table 1). 


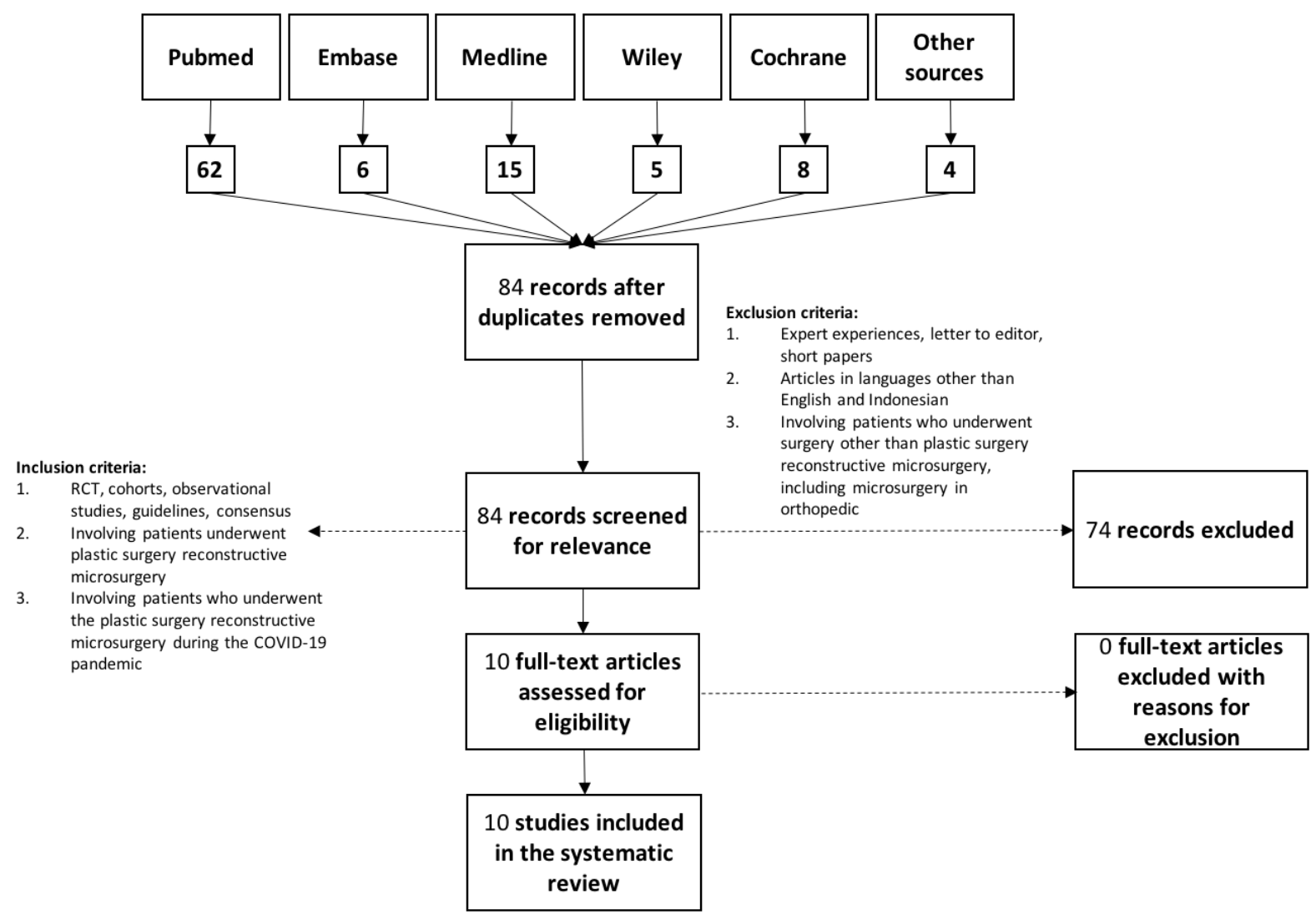

Figure 1. Studies focus on different aspects of reconstructive Microsurgery, including head and neck, breast, limb, and general Microsurgery.

We used critical appraisal of qualitative studies by the Center of Evidence-Based Medicine, the University of Oxford, for observational qualitative studies and guidelines. ${ }^{6,7}$.

All included qualitative studies had an appropriate qualitative approach. In general, studies look at various surgeon's experiences from different healthcare systems during the pandemic. All the included studies had sufficient descriptions of data collection methods and transparency, described the researcher's position, had good results, and had conclusions justified by the results. Their findings and recommendations may also be applied to other clinical settings, including to Author's healthcare system.

Nevertheless, all studies did not describe the steps to ensure quality control. Studies by Ducournau et al. and Patel et al. were considered inappropriate for the sampling strategy. We thought the sampling methods in those two studies could not have achieved the aims of the studies, as they mentioned. Studies by Allevi F et al., Ducournau F et al., and Patel RJ did not explain their strategy in obtaining the numbers of the selected participants or departments. Some variables might have had roles as confounding factors to the results pictured by each of the studies, yet they were not accounted for.

According to the critical appraisal of qualitative studies, Fuertes et al. have the best quality, with the most "yes" answers. This study did the sampling strategy appropriately. The Authors specified the included departments clearly, which were the departments in the thirdlevel hospitals with over 650 beds. None of the other included studies described clearly how the participants were chosen. This study also accounted for variables that might affect the surgical procedures in the hospital, such as the team access to PPE and education on COVID-19 received by the team. This study was initiated to 
know how the COVID-19 pandemic has affected the delivery of plastic surgery service in Spain, and it concluded that the number of elective microsurgical cases had been currently ceased. 8

All the included guidelines were specifically developed for the COVID-19 pandemic settings. Each guideline justified the benefit and harm in performing microsurgical reconstruction, patient's values, and the associated costs to the healthcare system. All authors considered the feasibility of their guidelines for various clinical settings. Guidelines by Lai et al., Martin et al., and Schoenbrunner et al. did not describe their inclusion criteria for their guidelines. Two guidelines, which are guidelines by Curigliano et al. and Hsieh et al., were made based on expert opinions and experiences. Meanwhile, the other studies, which are guidelines by Lai et al., Martin et al., and Schoenbrunner et al., were written based on literature reviews, peer consensus, and previously published recommendations. However, those guidelines failed to mention the inclusion criteria of the studies. According to the evidence level pyramid, both literature reviews and expert opinions are on the same level. Based on that, it can be thought that none of the included guidelines is more superior to the other, and all the relevant guidelines can be considered. These included guidelines range from breast cancer management, head and neck cancer reconstruction, and general microsurgical management. $3,4,11-13$

Table 1. Summaries of all included studies, including their aims, participants, methods, findings, and conclusions of each study, can be seen in

\begin{tabular}{|c|c|c|c|c|c|c|c|}
\hline $\begin{array}{l}\text { Title and } \\
\text { Authors }\end{array}$ & $\begin{array}{c}\text { Date of } \\
\text { Public } \\
\text { ation }\end{array}$ & $\begin{array}{l}\text { Types } \\
\text { of } \\
\text { Studies }\end{array}$ & Focus & Aims & Participants & $\begin{array}{l}\text { Methods (on how the } \\
\text { guidelines were } \\
\text { developed) }\end{array}$ & $\begin{array}{c}\text { Findings on } \\
\text { Microsurgical } \\
\text { Aspect }\end{array}$ \\
\hline \multicolumn{8}{|c|}{ Head and Neck Reconstructive Microsurgery } \\
\hline $\begin{array}{l}\text { Impact of } \\
\text { COVID-19 } \\
\text { epidemic on } \\
\text { maxillofacial } \\
\text { surgery in } \\
\text { Italy (Allevi } \\
\text { F, et al.) }\end{array}$ & $\begin{array}{l}\text { April } \\
23^{\text {rd, }} \\
2020\end{array}$ & $\begin{array}{l}\text { Qualita } \\
\text { tive } \\
\text { studies }\end{array}$ & $\begin{array}{l}\text { Maxillo } \\
\text { facial } \\
\text { surgery }\end{array}$ & $\begin{array}{l}\text { Impact of } \\
\text { Covid-19 } \\
\text { epidemic on } \\
\text { maxillofacial } \\
\text { surgery } \\
\text { departments in } \\
\text { Italy }\end{array}$ & $\begin{array}{l}23 \text { selected } \\
\text { Italian } \\
\text { maxillofacia } \\
\text { 1 surgery } \\
\text { department } \\
\text { s in Italy }\end{array}$ & $\begin{array}{l}\text { The questionnaire } \\
\text { collected anonymously } \\
\text { while keeping track of the } \\
\text { location of the } \\
\text { department }\end{array}$ & $\begin{array}{l}\text { All maxillofacial } \\
\text { activity, including } \\
\text { microsurgical } \\
\text { management, has been } \\
\text { highly reduced during } \\
\text { the first month of the } \\
\text { Covid-19 epidemic }\end{array}$ \\
\hline $\begin{array}{l}\text { Early } \\
\text { institutional } \\
\text { head and neck } \\
\text { oncologic and } \\
\text { microvascular } \\
\text { surgery } \\
\text { practice } \\
\text { patterns } \\
\text { across the } \\
\text { United States } \\
\text { during the } \\
\text { SARS-CoV-2 } \\
\text { (COVID19) } \\
\text { pandemic } \\
\text { (Patel RJ, } \\
\text { Kejner A) }\end{array}$ & $\begin{array}{l}\text { April } \\
8^{\text {th }} \\
2020\end{array}$ & $\begin{array}{l}\text { Qualita } \\
\text { tive } \\
\text { studies }\end{array}$ & $\begin{array}{l}\text { Head } \\
\text { and } \\
\text { neck } \\
\text { and } \\
\text { microv } \\
\text { ascular } \\
\text { surgery }\end{array}$ & $\begin{array}{l}\text { Monitoring } \\
\text { practice patterns } \\
\text { in order to } \\
\text { optimize } \\
\text { provider safety } \\
\text { and patient care } \\
\text { with "real-time" } \\
\text { methods }\end{array}$ & $\begin{array}{l}\text { Head and } \\
\text { neck } \\
\text { surgeons } \\
\text { from } 14 \\
\text { institutions } \\
\text { in the } \\
\text { United } \\
\text { States }\end{array}$ & Shared spreadsheet & $\begin{array}{l}\text { The Covid-19 } \\
\text { pandemic has caused a } \\
\text { reduction in head and } \\
\text { neck cancer care, } \\
\text { including } \\
\text { microsurgical } \\
\text { procedures. Online- } \\
\text { based platforms to } \\
\text { share practice patterns } \\
\text { will be essential as the } \\
\text { pandemic evolves. }\end{array}$ \\
\hline $\begin{array}{l}\text { Covid-19 } \\
\text { guidance } \\
\text { algorithm for } \\
\text { advanced } \\
\text { head and neck } \\
\text { cancer } \\
\text { reconstruction } \\
\text { (Hsieh MW, }\end{array}$ & $\begin{array}{l}\text { April } \\
24^{\text {th }} \\
2020\end{array}$ & $\begin{array}{l}\text { Guideli } \\
\text { nes }\end{array}$ & $\begin{array}{l}\text { Advan } \\
\text { ced } \\
\text { head } \\
\text { and } \\
\text { neck } \\
\text { cancer }\end{array}$ & $\begin{array}{l}\text { Providing clear } \\
\text { clinical pathway } \\
\text { from initial } \\
\text { survey, cancer } \\
\text { ablation, and } \\
\text { free flap } \\
\text { reconstruction } \\
\text { until }\end{array}$ & $\mathrm{N} / \mathrm{A}$ & $\begin{array}{l}\text { Experts developed the } \\
\text { guideline from } \\
\text { Kaohsiung Medical } \\
\text { University Hospital in } \\
\text { Kaohsiung, which has } \\
\text { specialized knowledge } \\
\text { about the content areas }\end{array}$ & $\begin{array}{l}\text { Surgeons should weigh } \\
\text { the benefits of } \\
\text { postponing surgery for } \\
\text { less aggressive cancers } \\
\text { to reduce the Covid- } 19 \\
\text { transmission against }\end{array}$ \\
\hline
\end{tabular}




\begin{tabular}{|c|c|c|c|c|c|c|c|}
\hline $\begin{array}{l}\text { Title and } \\
\text { Authors }\end{array}$ & $\begin{array}{l}\text { Date of } \\
\text { Public } \\
\text { ation }\end{array}$ & $\begin{array}{l}\text { Types } \\
\text { of } \\
\text { Studies }\end{array}$ & Focus & Aims & Participants & $\begin{array}{l}\text { Methods (on how the } \\
\text { guidelines were } \\
\text { developed) }\end{array}$ & $\begin{array}{c}\text { Findings on } \\
\text { Microsurgical } \\
\text { Aspect }\end{array}$ \\
\hline $\begin{array}{l}\text { Lee CC, Lu P, } \\
\text { Kuo Y) }\end{array}$ & & & $\begin{array}{l}\text { reconst } \\
\text { ruction }\end{array}$ & $\begin{array}{l}\text { postoperative } \\
\text { care on the } \\
\text { advanced head } \\
\text { and neck cancer } \\
\text { reconstruction }\end{array}$ & & $\begin{array}{l}\text { and evidence-based } \\
\text { medicine methodology. }\end{array}$ & $\begin{array}{l}\text { the risk for tumor } \\
\text { progression. }\end{array}$ \\
\hline $\begin{array}{l}\text { Head and } \\
\text { neck surgical } \\
\text { oncology in } \\
\text { the time of a } \\
\text { pandemic: } \\
\text { Subsite- } \\
\text { specific triage } \\
\text { guidelines } \\
\text { during the } \\
\text { COVID-19 } \\
\text { pandemic (Lai } \\
\text { SY et al.) }\end{array}$ & $\begin{array}{l}\text { May } \\
5^{\text {th }} \\
2020\end{array}$ & $\begin{array}{l}\text { Guideli } \\
\text { nes }\end{array}$ & $\begin{array}{l}\text { Head } \\
\text { and } \\
\text { neck } \\
\text { oncolo } \\
\text { gy } \\
\text { surgery }\end{array}$ & $\begin{array}{l}\text { Head and neck } \\
\text { surgical } \\
\text { oncology in the } \\
\text { time of a } \\
\text { pandemic: } \\
\text { Subsite-specific } \\
\text { triage guidelines } \\
\text { during the } \\
\text { COVID-19 } \\
\text { pandemic (Lai } \\
\text { SY et al.) }\end{array}$ & N/A & $\begin{array}{l}\text { The guideline was } \\
\text { developed by the MD } \\
\text { Anderson Head and } \\
\text { Neck Surgery Treatment } \\
\text { Guidelines Consortium } \\
\text { who has the specialized } \\
\text { knowledge of the content } \\
\text { areas. }\end{array}$ & $\begin{array}{l}\text { Surgical procedures on } \\
\text { basal cell carcinoma } \\
\text { and squamous cell } \\
\text { carcinoma, as well as } \\
\text { mastoid and temporal } \\
\text { bone surgery, should } \\
\text { be delayed. } \\
\text { Surgery can be } \\
\text { considered on several } \\
\text { occasions, such as } \\
\text { patients with } \\
\text { intermediate malignant } \\
\text { disease in the oral } \\
\text { cavity, early disease in } \\
\text { the oropharynx, } \\
\text { advanced } \\
\text { larynx/hypopharynx } \\
\text { diseases, high-grade } \\
\text { malignancies of the } \\
\text { salivary gland, } \\
\text { sarcomas that are not } \\
\text { candidates for } \\
\text { preoperative } \\
\text { chemotherapy, } \\
\text { advanced stage of } \\
\text { malignancies in the } \\
\text { endocrine system, } \\
\text { dental oncology, and } \\
\text { high-grade } \\
\text { ophthalmologic } \\
\text { malignancies. }\end{array}$ \\
\hline \multicolumn{8}{|c|}{ Limb Reconstructive Microsurgery } \\
\hline $\begin{array}{l}\text { COVID-19: } \\
\text { Initial } \\
\text { experience of } \\
\text { an } \\
\text { international } \\
\text { group of hand } \\
\text { surgeons } \\
\text { (Ducournau F, } \\
\text { et al) }\end{array}$ & $\begin{array}{l}\text { April } \\
9 \text { th, } 2020\end{array}$ & $\begin{array}{l}\text { Qualita } \\
\text { tive } \\
\text { studies }\end{array}$ & $\begin{array}{l}\text { Hand } \\
\text { surgery }\end{array}$ & $\begin{array}{l}\text { Describing the } \\
\text { different } \\
\text { measures taken } \\
\text { by hand } \\
\text { surgeons } \\
\text { around the } \\
\text { world in } \\
\text { response to the } \\
\text { Covid-19 } \\
\text { pandemic }\end{array}$ & $\begin{array}{l}7 \text { hand } \\
\text { surgeons } \\
\text { practicing } \\
\text { in } 34 \\
\text { different } \\
\text { countries }\end{array}$ & An online questionnaire & $\begin{array}{l}\text { Protocols were varied } \\
\text { in terms of visitors, a } \\
\text { health professional in } \\
\text { the operating room, } \\
\text { patient waiting areas, } \\
\text { wards, and emergency } \\
\text { rooms. }\end{array}$ \\
\hline $\begin{array}{l}\text { Managing } \\
\text { hand and } \\
\text { reconstructive } \\
\text { microsurgery } \\
\text { service during } \\
\text { COVID-19 } \\
\text { pandemic: } \\
\text { Singapore } \\
\text { experience } \\
\text { (Omar UF, } \\
\text { Yein TP, } \\
\text { Rajaratnam V) }\end{array}$ & $\begin{array}{l}\text { June } \\
10^{\text {th }} \\
2020\end{array}$ & $\begin{array}{l}\text { Qualita } \\
\text { tive } \\
\text { studies }\end{array}$ & $\begin{array}{l}\text { Hand } \\
\text { surgery }\end{array}$ & $\begin{array}{l}\text { Describing the } \\
\text { process of } \\
\text { auditing the } \\
\text { services of a } \\
\text { hand and } \\
\text { reconstructive } \\
\text { Microsurgery } \\
\text { and developing } \\
\text { strategies to } \\
\text { ensure the } \\
\text { continuity of the } \\
\text { services }\end{array}$ & $\begin{array}{l}\text { Hand and } \\
\text { reconstructi } \\
\text { ve } \\
\text { microsurger } \\
\text { y } \\
\text { attendance } \\
\text { and } \\
\text { procedures } \\
\text { conducted } \\
\text { at the Khoo } \\
\text { Teck Puat } \\
\text { Hospital, } \\
\text { Singapore, } \\
\text { before and } \\
\text { during the } \\
\text { Covid-19 } \\
\text { pandemic }\end{array}$ & Observational audit & $\begin{array}{l}\text { Maintaining essential } \\
\text { surgical services } \\
\text { during the pandemic } \\
\text { was possible through } \\
\text { rapid situational audits } \\
\text { and generating } \\
\text { localized strategies. }\end{array}$ \\
\hline
\end{tabular}

Copyright by Atmodiwirjo et al., (2021).

P-ISSN 2089-6492; E-ISSN 2089-9734 | DOI: 10.14228/jprjournal.v8i1.321 


\begin{tabular}{|c|c|c|c|c|c|c|c|}
\hline $\begin{array}{l}\text { Title and } \\
\text { Authors }\end{array}$ & $\begin{array}{l}\text { Date of } \\
\text { Public } \\
\text { ation }\end{array}$ & $\begin{array}{l}\text { Types } \\
\text { of } \\
\text { Studies }\end{array}$ & Focus & Aims & Participants & $\begin{array}{l}\text { Methods (on how the } \\
\text { guidelines were } \\
\text { developed) }\end{array}$ & $\begin{array}{l}\text { Findings on } \\
\text { Microsurgical } \\
\text { Aspect }\end{array}$ \\
\hline $\begin{array}{l}\text { Recommendat } \\
\text { ions for } \\
\text { triage, } \\
\text { prioritization, } \\
\text { and treatment } \\
\text { of breast } \\
\text { cancer } \\
\text { patients } \\
\text { during the } \\
\text { COVID-19 } \\
\text { pandemic } \\
\text { (Curigliano G } \\
\text { et al.) }\end{array}$ & $\begin{array}{l}\text { April } \\
16^{\text {th }} \\
2020\end{array}$ & $\begin{array}{l}\text { Guideli } \\
\text { nes }\end{array}$ & $\begin{array}{l}\text { Breast } \\
\text { cancer } \\
\text { manag } \\
\text { ement }\end{array}$ & $\begin{array}{l}\text { Presenting } \\
\text { recommendatio } \\
\text { ns to provide } \\
\text { guidelines, } \\
\text { including in } \\
\text { criteria selection } \\
\text { for service } \\
\text { provision and } \\
\text { prioritization of } \\
\text { management } \\
\text { based on the } \\
\text { pandemic } \\
\text { situation in each } \\
\text { country }\end{array}$ & $\mathrm{N} / \mathrm{A}$ & $\begin{array}{l}\text { The guideline was } \\
\text { developed by an expert } \\
\text { who has specialized } \\
\text { knowledge about the } \\
\text { content areas and applied } \\
\text { evidence-based medicine } \\
\text { methodology. }\end{array}$ & $\begin{array}{l}\text { Microsurgical } \\
\text { management for } \\
\text { breast } \\
\text { reconstruction } \\
\text { should not be } \\
\text { undertaken due } \\
\text { to the required } \\
\text { high resources. }\end{array}$ \\
\hline \multicolumn{8}{|c|}{ General reconstructive Microsurgery } \\
\hline $\begin{array}{l}\text { The current } \\
\text { impact of } \\
\text { Covid-19 } \\
\text { pandemic on } \\
\text { Spanish } \\
\text { plastic } \\
\text { surgery } \\
\text { departments: } \\
\text { a multi-center } \\
\text { report } \\
\text { (Fuertes V, } \\
\text { Monclus E, } \\
\text { Agullo A) }\end{array}$ & $\begin{array}{l}\text { April } \\
14^{\text {th }}, \\
2020\end{array}$ & $\begin{array}{l}\text { Qualita } \\
\text { tive } \\
\text { studies }\end{array}$ & $\begin{array}{l}\text { Plastic } \\
\text { surgery } \\
\text { depart } \\
\text { ments }\end{array}$ & $\begin{array}{l}\text { Knowing how } \\
\text { the Covid-19 } \\
\text { pandemic has } \\
\text { affected the } \\
\text { delivery of } \\
\text { plastic surgery } \\
\text { services in Spain }\end{array}$ & $\begin{array}{l}12 \text { selected } \\
\text { department } \\
\mathrm{s} \text { in Spain } \\
\text { have agreed } \\
\text { to } \\
\text { participate } \\
\text { in the } \\
\text { survey }\end{array}$ & $\begin{array}{l}\text { Questionnaire shared } \\
\text { through email }\end{array}$ & $\begin{array}{l}\text { Most electives surgery } \\
\text { plastic surgery } \\
\text { delivery, including } \\
\text { microsurgical } \\
\text { procedures, in the } \\
\text { Spanish Health System } \\
\text { was currently stopped } \\
\text { and has been severely } \\
\text { impacted by this } \\
\text { pandemic, especially in } \\
\text { keeping offering } \\
\text { emergency care. }\end{array}$ \\
\hline $\begin{array}{l}\text { Guidelines for } \\
\text { Microsurgery } \\
\text { During the } \\
\text { COVID-19 } \\
\text { Pandemic } \\
\text { (Martin F et } \\
\text { al.) }\end{array}$ & $\begin{array}{l}\text { April } \\
12^{\text {th }}, \\
2020\end{array}$ & $\begin{array}{l}\text { Guideli } \\
\text { nes }\end{array}$ & $\begin{array}{l}\text { Genera } \\
1 \\
\text { micros } \\
\text { urgical } \\
\text { manag } \\
\text { ement }\end{array}$ & $\begin{array}{l}\text { Providing } \\
\text { recommendatio } \\
\text { ns on how to } \\
\text { proceed. With } \\
\text { microsurgical } \\
\text { free tissue } \\
\text { transfer during } \\
\text { the Covid-19 } \\
\text { pandemic }\end{array}$ & N/A & $\begin{array}{l}\text { The Irish Microsurgery } \\
\text { Special Interest Group } \\
\text { developed the guideline } \\
\text { following literature } \\
\text { review and peer } \\
\text { consensus opinion. }\end{array}$ & $\begin{array}{l}\text { Free flap surgery } \\
\text { should be avoided } \\
\text { during the peak of the } \\
\text { Covid-19 pandemic, } \\
\text { and the locoregional } \\
\text { flap is preferred. Free } \\
\text { flaps should be the } \\
\text { most efficient and the } \\
\text { simplest. Bone-free } \\
\text { flaps should be } \\
\text { avoided due to the } \\
\text { aerosolized virus that } \\
\text { can be generated. }\end{array}$ \\
\hline $\begin{array}{l}\text { A Summary of } \\
\text { Recommendat } \\
\text { ions for } \\
\text { Plastic } \\
\text { Surgeons } \\
\text { During the } \\
\text { COVID-19 } \\
\text { Outbreak } \\
\text { (Schoenbrunn } \\
\text { er AR, Sarac } \\
\text { BA, Janis JE) }\end{array}$ & $\begin{array}{l}\text { June } \\
26^{\text {th }} \\
2020\end{array}$ & $\begin{array}{l}\text { Guideli } \\
\text { nes }\end{array}$ & $\begin{array}{l}\text { Electiv } \\
\mathrm{e} \\
\text { plastic } \\
\text { surgery } \\
\text { proced } \\
\text { ures }\end{array}$ & $\begin{array}{l}\text { Guiding elective } \\
\text { plastic surgery } \\
\text { procedures } \\
\text { during the } \\
\text { Covid-19 } \\
\text { outbreak }\end{array}$ & $\mathrm{N} / \mathrm{A}$ & $\begin{array}{l}\text { Plastic surgeons } \\
\text { developed the guideline } \\
\text { in The Ohio State } \\
\text { University Wexner } \\
\text { Medical Center by } \\
\text { reviewing } \\
\text { recommendations issued } \\
\text { by state governing bodies } \\
\text { and national society and } \\
\text { federal guidelines. }\end{array}$ & $\begin{array}{l}\text { Elective interventions } \\
\text { in plastic surgery, } \\
\text { including } \\
\text { microsurgical } \\
\text { reconstruction, must } \\
\text { be postponed to } \\
\text { preserve limited } \\
\text { resources and } \\
\text { minimize exposure } \\
\text { risk. }\end{array}$ \\
\hline
\end{tabular}

The types of included studies varied from expert opinions, qualitative observational studies, and guidelines. We only include observational qualitative studies and guidelines due to a higher level of evidence. The focuses of the included studies are also diverse from head and neck surgery, breast surgery, limb surgery, and general Microsurgery. ${ }^{3-5,8-13}$ 


\section{DISCUSSION}

\section{General Recommendation}

This systematic review has identified articles of reconstructive microsurgical procedures in the COVID-19 pandemic setting. All included qualitative studies show that measures taken by reconstructive microsurgeons around the world were not homogenous. There has been no international consensus nor recommendation for surgical management during the COVID-19 pandemic by the WHO so far. This is why most practicing reconstructive microsurgeon only comply with local policies carried out by their hospital or professional association. $^{9}$

In general, microsurgical reconstruction has not been suggested during the peak of the pandemic. Unfortunately, patients who undergo free flaps occupy more resources at the healthcare system and stay more extended periods in the facility. While during this critical condition, more hospital beds may be needed for COVID-19 patients. ${ }^{3,8,12}$ A survey of 14 head and neck cancer centers in the USA showed that 12 out of 14 still perform surgeries during the COVID-19 pandemic, even free flaps. ${ }^{10}$ Hsieh et al. divided the pandemic situation into four classes of severities. 4 For the highest severity, or at the peak of the COVID-19 pandemic, it is recommended to put any surgery on hold.4,12 As for any planned microsurgical reconstruction is of utmost importance to mitigate the risk while providing adequate reconstructive care. ${ }^{2}$

\section{Outpatients}

During the pandemic's peak, as seen in the rising graph of confirmed cases over time, microsurgery outpatient clinics should be either replaced by telephone or video consultation. All manual visits are limited to urgent visits only. ${ }^{10-11}$ Ranasinghe et al. recommended telemedicine video meetings with all patients using tablets or smartphones to replace regular outpatient visits in any phase of the pandemic. Even though telemedicine limits any direct physical examination such as extremity pulses, it allows assessment of tumor sizes, anticipated defects, some anatomy, and functions. If a direct physical examination is needed, it should be done in the preoperative holding area, just before the surgery started. ${ }^{2}$

\section{Patients Selection}

In-depth discussion and careful patient selection through the multi-disciplinary team (MDT) is crucial to justify the benefit and harms of performing microsurgical reconstruction during the COVID-19 pandemic and prioritizing hospital resources for COVID-19 patients. ${ }^{2,3,10-12}$ Any MDT meetings or boards should be performed over an online video conference. . $^{2,10,11}$

In the oncologic patient population, postponing surgery can deliberately impact survival due to the increased risk of cancer upstaging to the point of irreversibility.4,11 On the other hand, cancer patients also at higher risk for COVID-19 related adverse events such as death or ICU admissions requiring ventilator support. ${ }^{4}$

Selected patients may be deferred. Oncologic cases that can be considered for deferral are those that are benign, has low-grade malignancy, for prophylactic intent, and unlikely to cause adverse effects by an 8 - 12 week surgical delay or other appropriate alternative therapies are available. ${ }^{2,3,8,11}$ Ranasinghe et al. also recommend postponing any free flap reconstruction for non-oncologic indications such as post-traumatic, osteoradionecrosis, and wounds. ${ }^{2}$ Surgical procedures may be unsafe for advanced-stage malignancies because of the possibility of more extended hospitalization that increases COVID-19 transmission, exacerbated by deteriorating immune condition. 3,11

For microsurgical limb reconstructions such as trauma, all preventive measures were generally the same with head ad neck reconstruction. However, it is advisable to push back all autologous free flaps plans after the COVID-19 peak for breast reconstruction. Immediate implant-based reconstruction may be offered in select patients. ${ }^{12}$

\section{Preoperative}

COVID-19 positive patients without any symptoms is a significant concern. It is recommended that all patients who are planned for reconstructive microsurgical procedures undergo COVID-19 testing preoperatively.2,10-11,13 Lai et al. recommend testing all patients with mucosal lesions before head and neck surgery evaluation, or at least one day before surgery. ${ }^{11}$ Schoenbrunner et al. summarised that Polymerase Chain Reaction (PCR) test should be conducted for all inpatients and outpatients within five days of their surgery date, with self- 
quarantine in between to minimize interval exposure. ${ }^{12,13}$ Hsieh et al. recommended the same testing with additional Chest $\mathrm{CT}$ if positive plain film findings suggested COVID-19.4

Surgery should be postponed if the patient is COVID-19 positive or has COVID-19 like symptoms unless a significant lifethreatening situation that necessitates surgery occurred due to its higher mortality rates in the postoperative period.2,11 For COVID-19 positive patients who must otherwise be scheduled for surgery, Hsieh et al. recommend admitting them to the negative pressure isolation ward, through specifically designated in-hospital transport routes, in the same bed, with the same nurse team. ${ }^{4}$

\section{Personal Protective Equipment (PPE)}

Full PPE (Personal Protective

Equipment) is recommended for all high-risk procedures for COVID-19 transmissions that involve mucosal or aerodigestive tract, including tracheostomy, which also pertains to the head and microsurgical neck reconstruction. ${ }^{2,10}$ While there is a lack of consensus for PPE usage, only $29 \%$ of the survey respondent would wear standard surgical PPE for patients with negative or undetermined preoperative COVID-19 testing. ${ }^{10}$ This might be attributed to the alarming rate of false-negative results of COVID-19 testing. ${ }^{2}$ Martin et al. suggest treating all patients as COVID-19 positives. Therefore full PPE must be used.12 Interestingly, a guideline from Hsieh et al. advocates using surgical masks and standard PPE for COVID-19 negative cases. ${ }^{4}$ It could be due to the region where the Author resides having a lower number of COVID-19 cases.

The recommended full PPE across studies includes Powered Air Purifying Respirators (PAPR) system, fit-tested N95 respirator masks, face shield, along tight-fitting eye protection goggles. ${ }^{4,10,11}$ For any confirmed COVID-19 cases, it is recommended to use PAPR. ${ }^{11}$ Full PPE must always be worn during the entire procedure, even in lengthy microsurgical reconstruction. As PPE may become scarce during the pandemic, it is advisable to conserve PPE by reducing the operating team sizes, limit personnel in-n-outs, and perform two team approaches. ${ }^{2}$

With this full PPE, microsurgical perforator dissection using loupes and microvascular anastomosis through an electronic microscope can be challenging. ${ }^{11,12}$ while the known side effect of prolonged use of the N95 mask includes lightheadedness and headache. ${ }^{2}$ The authors suggest Full PPEs applications that allow surgeons to dissect out perforator using loupes and anastomose vessel using an electronic microscope comfortably (Figures 2 and 3).
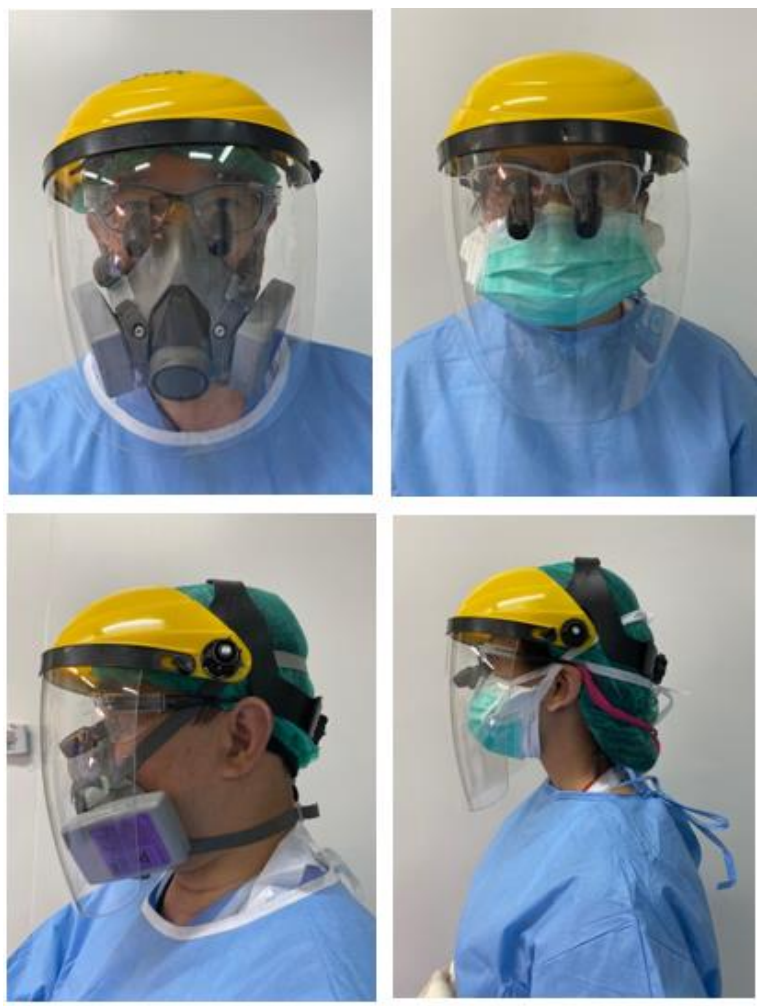

Figure 2. Suggestions on Full PPE combinations for comfortable Microsurgery performances.

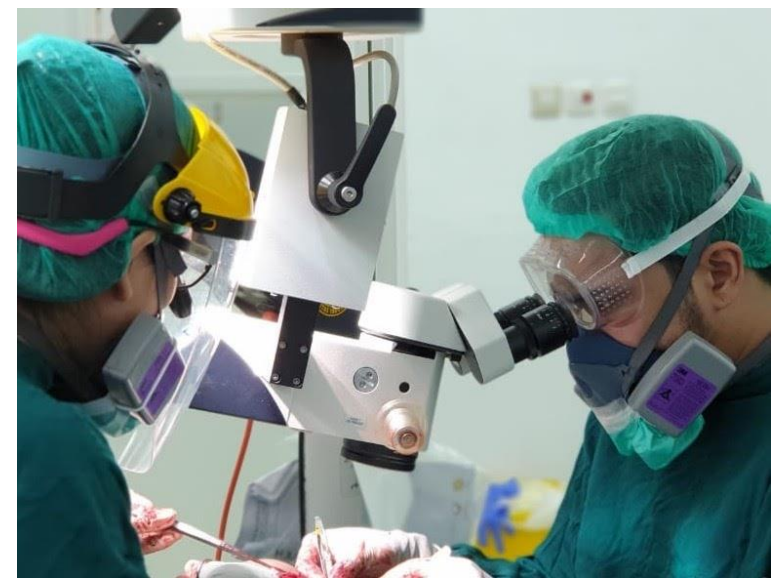

Figure 3. Using Full PPEs while performing Microsurgical anastomosis 


\section{Intraoperative}

The most efficient surgical option should be indicated to minimize returning to the operating room and accelerate patient discharge. If indicated, microsurgical reconstruction choice should be the most efficient and most straightforward. Free flaps with larger diameter vessels may be indicated to avoid using microscopes with full PPE. ${ }^{12}$ However, the Author finds using tight-fitted eye goggles with antifog features quite comfortable for anastomosing the vessel using a microscope. For head and neck reconstruction, locoregional flaps should be the preferred reconstructive option as the procedure is more straightforward and more efficient. 2,12 Microsurgical free flaps were done if necessary according to the MDT; these include anterior oromandibular defects, $>50 \%$ tongue and floor of mouth defects, laryngectomy, and skull base defects. ${ }^{2}$

Surgery should be performed in a designated COVID-19 free zone with negative pressure theatre. High air exchanged with cycle rated $>25$ cycles per hour should be maintained in the theatre. ${ }^{12}$ Following intubation, a period of 15 minutes should be allowed for gas exchange before the entry of surgical teams. ${ }^{2,4,12}$ The number of staff in the operating room has also been advisable to be minimized.2,11,12

Measures should be taken to reduce aerosolization during surgery. Tracheostomy can decrease aerosolization, and diathermy should be set to the lowest adequate settings to minimize aerosolization. 2,4,12 Bone-free flaps should be avoided as power devices may generate aerosolized viruses, and the risk of transmission will be higher. 2,12

\section{Postoperative}

Following ICU step-downs, patients should be nursed in a presumed COVID-19 negative ward postoperatively, ideally in an isolated room.2,12 Any COVID-19 positive patients should be admitted to the same negative pressure isolation ward and managed with the same nurse team as preoperatively. ${ }^{4}$

Postoperative flap checks should be considered high risk and done with full PPE, including N95 mask, gown, and protective eyewear. ${ }^{2,12}$ Monitoring should be limited to reduce both the risk of COVID-19 exposure and the PPEs needed for flap checks. Continuous implantable doppler for arterial and venous monitoring is suggested. ${ }^{2}$ Ranasinghe et al. modified their flap checks protocol as follows, residents flap checks every 6 hours immediately post-op and once in the morning rounds, while nurse flap checks limited to check for implantable Doppler signal and external skin paddle every 6 hours or if there are signal changes. ${ }^{2}$ Martin et al. recommended one check at 2 hours postoperatively and once every day. ${ }^{12}$

Splitting teams and minimizing interaction between them through virtual meetings, separate rounding times, and elimination of shared workspaces are recommended. These are ways to decrease COVID-19 exposure and to prepare if one team is quarantined. 2 The reconstructive microsurgical team assigned to any procedures for COVID-19 confirmed patients must be tested for COVID-19 after and quarantined for a minimum of 2 weeks. The team members can resume work only after full clearance of infection status and completion of quarantine. ${ }^{4}$

\section{LIMITATIONS}

There have been various studies regarding microsurgical procedures in the Covid19 pandemic. However, most of the available studies have a low level of evidence. This might be because information regarding microsurgical management in this critical period must be obtained quickly. Rapid data gatherings can support in creating the most proper recommendations in handling patients during this situation.

\section{CONCLUSION}

Microsurgical reconstruction is not suggested to perform during the peak of the COVID-19 pandemic. It is indicated only if necessary after a rigorous review by the multidisciplinary team. A full PPE, including a Powered Air Purifying Respirators (PAPR) system, fit-tested N95 respirator masks, face shield, and tight-fitting eye protection goggles, are recommended in performing the surgeries. Any more straightforward and faster microsurgical reconstruction options would be recommended to be mandated to reduce the risk of COVID-19 transmission. 
Correspondence regarding this article should be addressed to:

Parintosa Atmodiwirjo, M.D. Division of Plastic Surgery, dr. Ciptomangunkusumo Hospital, Medical Staff Wing, Building A, 4th Floor, Jalan Diponegoro no 71, Salemba, Jakarta Pusat, 10310, Indonesia.

Email: parintosa.atmodiwirjo@ui.ac.id

\section{REFERENCES}

1. WHO. WHO Coronavirus Disease (COVID19) Dashboard [Internet]. Covid19.who.int. 2020 [cited 23 June 2020]. Available from: https://covid19.who.int/

2. Ranasinghe V, Mady L, Kim S, Ferris R, Duvvuri U, Johnson J et al. Major head and neck reconstruction during the COVID-19 pandemic: The University of Pittsburgh approach. Head \& Neck. 2020;42(6):1243-7.

3. Curigliano G, Cardoso M, Poortmans $P$, Gentilini O, Pravettoni G, Mazzocco K et al. Recommendations for triage, prioritization, and treatment of breast cancer patients during the COVID-19 pandemic. The Breast. 2020;52:8-16.

4. Hsieh M, Lee C, Lu P, Kuo Y. Covid-19 guidance algorithm for advanced head and neck cancer reconstruction. Microsurgery. 2020:1-2.

5. Allevi F, et al. Impact of COVID-19 epidemic on maxillofacial surgery in Italy. British Journal of Oral and Maxillofacial Surgery. 2020:2-7.

6. CEBM. Critical Appraisal tools - CEBM [Internet]. CEBM. 2020 [cited 7 June 2020]. Available from: https://www.cebm.net/2014/06/criticalappraisal/

7. Clubb AB, Dahm P. How to critically appraise a clinical practice guideline. Indian J Urol. 2011;27(4):498-502.

8. Fuertes V, Monclús E, Agulló A. Current impact of Covid-19 pandemic on Spanish plastic surgery departments: a multi-center report. European Journal of Plastic Surgery. 2020:1-8.

9. Ducournau F, et al. COVID-19: Initial experience of an international group of hand surgeons. Hand Surgery and Rehabilitation. 2020;39(3):159-66.

10. Patel R, Kenner A, McMullen C. Early institutional head and neck oncologic and microvascular surgery practice patterns across the United States during the SARSCoV -2 ( COVID19) pandemic. Head \& Neck. 2020;42(6):1168-72.

11. Lai SY, et al. Head and neck surgical oncology in the time of a pandemic: Subsitespecific triage guidelines during the COVID -19 pandemic. Head \& Neck. 2020;42(6):1194-201.

12. Martin F, et al. Guidelines for Microsurgery during the COVID-19 pandemic. Irish Microsurgery Special Interest Group. 2020:16.

13. Schoenbrunner AR, Sarac BA, Janis JE. A summary of recommendations for plastic surgeons during the COVID-19 outbreak. PRS-Global Open. 2020:1-23

14. Satuan Tugas Penanganan COVID-19. Beranda | Covid19.go.id [Internet]. covid19.go.id. 2021 [cited 15 April 2021]. Available from: https://covid19.go.id/ 